\title{
WEDIRIL ENUALIOK
}

\section{TRAINING WORKSHOP ON PERFORMANCE-BASED ASSESSMENT: FEEDBACK OF THE PARTICIPANTS FACULTY}

Rano Mal Piryani ${ }^{1, *}$, Suneel Piryani ${ }^{2}$

${ }^{1}$ Department of Internal Medicine and Medical Education, Chitwan Medical College, Bharatpur, Chitwan, Nepal

${ }^{2}$ Department of Community Medicine and Public Health, Chitwan Medical College, Bharatpur, Chitwan, Nepal

Received: 16 Nov, 2018

Accepted: 20 March, 2019

Published: 31 March, 2019

Key words: Assessment; Faculty; Health profession education; Performancebased assessment; Training.

*Correspondence to: Rano Mal Piryani, Department of Internal Medicine and Medical Education, Chitwan

Medical College, Bharatpur, Chitwan, Nepal Email:r_piryani@hotmail.com

\section{Citation}

Piryani RM, Piryani S. Training workshop on performance-based assessment: feedback of the participants faculty. Journal of Chitwan Medical College. 2019; 9 (27): 61-65.

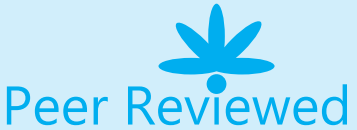

\begin{abstract}
Background: Performance-based assessment (PBA) concentrate on "Does" level of Miller's Triangle Model of assessment and assess the ability of healthcare professionals to practice safely in different situations and context. It is essential to train faculty members how to conduct PBA.
\end{abstract}

Methods: One-day training workshop on PBA was organized at Liaquat University of Medical \& Health Sciences Jamshoro, Sindh Pakistan in November 08, 2017 with objective "participants learn to apply PBA tools in practice". There were two sessions of training; session one covered basics, levels and tools of assessment and blueprinting for assessment and session two PBA and its tools. Tutorial, brainstorming and activity based small group work were methods utilized for the training. Feedback of the participants was taken on semi-structured questionnaire. Descriptive analysis was done using SPSS.

Results: Twenty-two participants selected from basic, clinical, and dental sciences and nursing faculty. The participants rated workshop on scale of 1-10 (1=poor, 10=excellent) for usefulness of training $(8.64 \pm 1.62)$, content of training $(8.27 \pm 1.52)$, relevance of training \& content $(8.59 \pm 1.40)$, facilitation of training $(8.77 \pm 1.34)$ and overall $(8.77 \pm 1.38)$. After training participants were very confident in developing blueprint for assessment $(3.91 \pm 0.61)$, using mini-CEX (3.64 \pm 0.58$)$, and confident using DOPS (3.63 \pm 0.73$),$ MSF $(3.55 \pm 0.74)$ and Portfolio (3.68 \pm 0.84$)$. More than one third of the participants recommended to arrange more training workshop on different aspects of medical education.

Conclusions: It was observed from feedback that participants realize the importance of PBA training and stress to have trainings for various aspects of health profession education.

\section{INTRODUCTION}

It is said that "assessment drives the learning". The main purpose of assessment is to enhance the learning of the students and its impact on learning of the students. ${ }^{1-3}$

The practice of medicine is very complex, composite and multifaceted process; the knowledge, skills, attitude, competence and performance are the key attributes of it. It is noticed that competence may not predict performance, so the performance-based assessment (PBA) at the work place in multiple context and settings, an essential component of the assessment must be the part of students' assessment process. ${ }^{3,4}$

PBA based tools focus on "Does" level of Miller's Triangle Model of assessment and assess the ability and capacity of healthcare professionals to practice safely and securely in different settings and context. ${ }^{1-3}$ 
The several tools have been developed to assess the performance of students at "Does" level like mini-Clinical Evaluation Exercise (mini-CEX), Directly Observed Procedure Skills (DOPS), 360 degree or Multi Source Feedback (MSF), Portfolio.. ${ }^{5-11}$

The objective of this study was to get feedback of the participant faculty members for training workshop on "Performance Based Assessment".

\section{METHODS}

One-day training workshop on "Performance Based Assessment" was organized at Directorate of Medical Education, Liaquat University of Medical \& Health Sciences (LUMHS) Jamshoro/Hyderabad, Sindh Pakistan in November 08, 2017. The objective of the workshop was "participants learn to apply performance-based assessment tools in practice.

The resource persons (R M Piryani, principle author \& Suneel Piryani, co-author) designed the program schedule of training workshop and conducted workshop. There were two sessions of training workshop. The sub-sessions of session one covered1) Basic of assessments 2) Level of assessment and tools/methods of assessment based on Miller's Triangle Model of assessment, 3) Blueprinting for assessment and session two was on Performance Based Assessment \& its tools.

Miller's Triangle Model attempts to stage clinical competence and performance at four levels.1

-Level one "Know"- tools used to test facts (knowledge)

-Level two "Knows How"- tools used to test context (understanding)

-Level three "Shows How"- tools used to test competence

-Level four "Does"- tool used to test performance.

LUMHS selected 22 participants from among the basic sciences, clinical sciences, dental sciences and nursing faculty members. Tutorial, brainstorming and activity based small group work and discussion were methods utilized for the training workshop.

At the end of training workshop, written feedback of the participants was taken with their consent on semi-structured questionnaire. The questionnaire contained nine questions; first six were closed ended and last three were open ended. The question one was on rating the training workshop at scale 1-10 (1=poor and 10=excellent) for its usefulness, content, relevance, facilitation and overall rating. The questions two to six were on the level of confidence of participants after participation in training workshop about developing blueprint for assessment, using miniCEX, using DOPS, using 360 degree (MSF) and using Portfolio respectively. The questions two to six were rated at Likert scale 1-5 ( $5=$ highly confident, $4=$ very confident, $3=$ confident, $2=$ to some extent confident $1=$ not confident). The question seven were about good points of workshop, eight on area of improvement and nine for additional comments.

The collected data was checked for completeness, accuracy and consistency and entered in IBMS SPSS version 21 for analysis. Descriptive analysis was done. The frequency, mean and standard deviation were computed.

\section{RESULTS}

Twenty-two faculty members participated in the training workshop on performance-based assessment (PBA).

Faculty members rated the workshop on scale of 1-10 (1= poor, $10=$ excellent); rating on workshop were notable. (Table 1 )

Table 1: Rating of Faculty members for training workshop on performance-based assessment (PBA)

\begin{tabular}{|l|l|l|}
\hline Q-1 & Items of question one & $\begin{array}{l}\mathbf{R} \text { a } \mathrm{t} \text { i } \mathrm{n} \mathrm{g} \\
\text { (Mean } \pm \\
\text { SD) }\end{array}$ \\
\hline & $\begin{array}{l}\text { Usefulness of training (Scale } \\
1-10)\end{array}$ & $8.64 \pm 1.62$ \\
\hline & $\begin{array}{l}\text { Content of training (Scale 1-10) } \\
8.27 \pm 1.52\end{array}$ \\
\hline $\begin{array}{l}\text { Relevance of training \& content } \\
\text { (Scale 1-10) }\end{array}$ & $8.59 \pm 1.40$ \\
\hline $\begin{array}{l}\text { Facilitation of training (Scale } \\
1-10)\end{array}$ & $8.77 \pm 1.34$ \\
\hline & Overall (Scale 1-10) & $8.77 \pm 1.38$ \\
\hline
\end{tabular}

Mean and frequency with percentage of the confidence level of the participants on 5-points Likert's scale ranging from highly confident to not confident are given in table 2 . The findings are remarkable. 
Table 2: Mean and frequency with percentage of the confidence level of the participants on 5-points Likert's scale (highly confident to not confident) after participation in training workshop on performancebased assessment (PBA)

\begin{tabular}{|l|l|l|l|l|l|l|}
\hline Question & $\begin{array}{l}\text { Highly confi- } \\
\text { dent }\end{array}$ & $\begin{array}{l}\text { Very } \\
\text { confi- } \\
\text { dent }\end{array}$ & $\begin{array}{l}\text { Confi- } \\
\text { dent }\end{array}$ & $\begin{array}{l}\text { To } \\
\text { some } \\
\text { extent } \\
\text { confi- } \\
\text { dent }\end{array}$ & $\begin{array}{l}\text { Not } \\
\text { confi- } \\
\text { dent }\end{array}$ & $\begin{array}{l}\text { Mean } \pm \\
\text { SD }\end{array}$ \\
\cline { 2 - 7 } & No. (\%) & No. (\%) & No. (\%) & No. (\%) & No. (\%) & \\
\hline $\begin{array}{l}\text { 2. Develops blueprint for assess- } \\
\text { ment of my subject }\end{array}$ & $05(22.7)$ & $14(63.7)$ & $3(13.6)$ & $0(0.0)$ & $0(0.0)$ & $3.91 \pm 0.61$ \\
\hline 3. Uses mini-CEX as a tool of PBA & $09(40.9)$ & $12(54.6)$ & $1(4.5)$ & $0(0.0)$ & $0(0.0)$ & $3.64 \pm 0.58$ \\
\hline 4. Uses DOPS as a tool of PBA & $02(9.1)$ & $05(22.7)$ & $14(63.7)$ & $1(4.5)$ & $0(0.0)$ & $3.63 \pm 0.73$ \\
\hline $\begin{array}{l}\text { 5. Uses 360 degree (MSF) as a tool } \\
\text { of PBA }\end{array}$ & $02(9.1)$ & $7(31.8)$ & $12(54.6)$ & $1(4.5)$ & $0(0.0)$ & $3.55 \pm 0.74$ \\
\hline 6. Uses Portfolio as a tool of PBA & $02(9.1)$ & $06(27.3)$ & $11(50.0)$ & $3(13.6)$ & $0(0.0)$ & $3.68 \pm 0.84$ \\
\hline
\end{tabular}

Table 3: Good points of for training workshop on performance-based assessment shared by the participants

\begin{tabular}{|l|l|}
\hline Good Points & $\begin{array}{l}\text { No of the } \\
\text { partici- } \\
\text { pants }\end{array}$ \\
\hline Well conducted training workshop & 7 \\
\hline Excellent Facilitation & 6 \\
\hline $\begin{array}{l}\text { Encouragement for learning in friend- } \\
\text { ly environment }\end{array}$ & 5 \\
\hline Excellent communication & 4 \\
\hline Interactive training & 4 \\
\hline Very informative training & 3 \\
\hline Learnt new methods of assessment & 2 \\
\hline $\begin{array}{l}\text { Opportunity to develop blue print of } \\
\text { my department }\end{array}$ & 1 \\
\hline $\begin{array}{l}\text { Learnt how to effectively assess the } \\
\text { students }\end{array}$ & 1 \\
\hline $\begin{array}{l}\text { Excellent command of resource per- } \\
\text { sons on subject }\end{array}$ & 1 \\
\hline $\begin{array}{l}\text { Simple and easily understandable } \\
\text { language used }\end{array}$ & 1 \\
\hline $\begin{array}{l}\text { Learnt performance-based assess- } \\
\text { ment first time }\end{array}$ & 1 \\
\hline $\begin{array}{l}\text { Very difficult concept made easy for } \\
\text { understanding by resource persons }\end{array}$ & 1 \\
\hline Good topics & 1 \\
\hline
\end{tabular}

Performance Based Assessment (PBA), miniCEX (Mini Clinical Evaluation Exercise), DOPS (Directly Observed Procedure Skills), MSF (Multi Source Feedback)

Good points of the training workshop on performancebased assessment and area for improvement shared by the participants are given in tables $3 \& 4$ respectively.

Table 4: Area for improvement in training workshop on performance-based assessment shared by the participants

\begin{tabular}{|l|l|}
\hline Area for improvement & $\begin{array}{l}\text { No of the } \\
\text { participants }\end{array}$ \\
\hline Arrange backup for power supply & 4 \\
\hline Provide quality food & 4 \\
\hline $\begin{array}{l}\text { More time is required for such } \\
\text { workshop }\end{array}$ & 3 \\
\hline Provide handout of proceedings & 3 \\
\hline $\begin{array}{l}\text { Basics of assessment must be ex- } \\
\text { plained in little bit detail }\end{array}$ & 1 \\
\hline $\begin{array}{l}\text { More time for practice in group } \\
\text { work }\end{array}$ & 1 \\
\hline Explain with diagrams & 1 \\
\hline Arrange good audiovisual aids & 1 \\
\hline Improve overall management & 1 \\
\hline
\end{tabular}

Eight of the participants (36.36\%) recommended to management to arrange more such sort of training workshop on different aspects of health professions 
education and one each of the participants recommended to improve standard of assessment in university and integrated PBA in the curriculum of university.

\section{DISCUSSION}

The performance-based assessment is an essential and fundamental component of overall assessment activities for the students of healthcare professions. It is multifaceted and integral as teaching, learning, assessment and feedback are closely integrated in this process. PBA is implemented at workplace, so it is also called as workplace-based assessment conducted in different context and settings. The trainee students are judged against the certain standard criteria that they are expected to attain at different stages of training.3, 4, 6, 9, 11- 13

DOPS, MSF, miniCEX and Portfolio are some the tools used for PBA.5, 7, 8, 10 During the training workshop on PBA faculty members were briefed about these tools, their importance and use.

Blueprint is a map with specification that links assessment with learning objectives and deals with the sampling content, competencies and assessment tools for the assessment with a logical and balanced approach.14, 15 The participants during this training workshop on PBA were sensitized about the blueprinting, its importance, weightage and use.

The critical reflections in the form of feedback serves guide for improvement.16 The feedback of the participants of training workshop on PBA was remarkable and noteworthy.

The participants rated the workshop on scale of 1-10 (1= poor, $10=$ excellent) for usefulness of training (8.64 \pm 1.62$)$, content of training (8.27 \pm $1.52)$, relevance of training \& content $(8.59 \pm 1.40)$, facilitation of training $(8.77 \pm 1.34)$ and overall $(8.77$ $\pm 1.38)$.

After training participants felt very confident for developing blueprint for the assessment in their department (3.91 \pm 0.61 ), using mini-CEX as a tool for PBA (3.64 \pm 0.58$)$, and confident using DOPS as a tool for PBA (3.63 \pm 0.73$),$ MSF as a tool for PBA (3.55 \pm 0.74$)$ and Portfolio as a tool for PBA (3.68 \pm 0.84$)$.

Well conducted training workshop, excellent facilitation, encouragement for learning in friendly environment, excellent communication, interactive training, very informative training and learnt new methods of assessment were among the good points of training workshop on PBA shared by the participants.

Participants suggested to management of Directorate of Medical Education of LUMHS arrange backup for power supply, provide quality food, extend time for such workshop, provide handout of proceedings, arrange good audiovisual aids and improve overall management while suggestions for the resource person were explain basics of assessment in little bit detail, provide more time for group work and explain subject in diagram.

More than one third of the participants recommended to management to arrange more such sort of training workshop on different aspects of medical education.

It is observed and noticed from feedback of the participants that they realize the importance of training, demand and need training for various aspects of health profession education including assessment and eager and keen to learn about health profession education.

\section{REFERENCES}

1. Vergis A, Hardy K. Principles of Assessment: A Primer for Medical Educators in the Clinical Years. The Internet Journal of Medical Education. 2009; 1 (1): 1-9. http://ispub.com/IJME/1/1/13042.

2. Rezigalla, et al. The impact of continuous assessment on the final results a case study: College of Medicine, King Khalid University. Sudan Medical Monitor October 2014; 9 (1): 48-150. https://dx.doi.org/10.4103/1858-5000.153029

3. Nair BR, Parsons: K. Performance-based assessment: Innovation in medical education Archives of Medicine and Health Sciences Jul-Dec 2014; 2 (2): 123-125. https://dx.doi. org/10.4103/2321-4848.144292

4. Performance Based Assessment Preparation Guide College of Dieticians of Ontario Prepared in February 2017. https://www.collegeofdietitians. 
org/resources/registration/kcat-(competencyassessment)/pba-preparation-guide.aspx

5. Mortaz Hejri et al. The utility of mini-Clinical Evaluation Exercise (mini-CEX) in undergraduate and postgraduate medical education: protocol for a systematic review. Systematic Reviews. 2017; 6:146. https://dx.doi.org/10.1186/s13643-0170539-y

6. Patricia JH et all. A novel workplace- based assessment for competency-based decisions and learner feedback. Medical Teacher. 2018; 40(11): 1143-50. https://dx.doi.org/10.1080/014215 9X.2018.1461204

7. Dannefer EF, Henson LC. The portfolio approach to competency-based assessment at the Cleveland Clinic Lerner College of Medicine. Academic Medicine. 2007 May 1;82(5):493-502. https:// dx.doi.org/10.1097/ACM.0b013e31803ead30

8. Profanter et al.: DOPS (Direct Observation of Procedural Skills) in undergraduate skills-lab: Does it work? Analysis of skills-perfprmance and curricular side effects. GMS Zeitschrift für Medizinische Ausbildung. 2015; Vol. 32(4). https://dx.doi.org/10.3205/zma000987

9. Norcini JJ McKinley DW. Assessment methods in medical education. Teaching and Teacher Education. 2007; 23(3): 239-250. https://doi. org/10.1016/j.tate.2006.12.021

10. Doherty EG, Brodsky D. The 360-degree assessment: a new paradigm in trainee evaluation. NeoReviews. April 2011: 12(4); e195 https://neoreviews.aappublications.org/ content/neoreviews/12/4/e191.full.pdf
11. Tabish SA. Assessment Methods in Medical Education. Int J Health Sci (Qassim). 2008 Jul; 2(2): 3-7. https://www.ncbi.nlm.nih.gov/pmc/ articles/PMC3068728/

12. Epstein R M. Assessment in medical education. N Engl J Med 2007; 356:387-96. https://dx.doi. org/10.1056/NEJMra054784

13. Hurst YK, Preescott-Clements L. Optimizing workplace-based assessment. The Clinical Teacher 2018; 15: 7-12. https://doi.org/10.1111/ tct.12730

14. Patil SY, Gosavi M, Bannur HB, Ratnakar A. Blueprinting in assessment: $A$ tool to increase the validity of undergraduate written examination in pathology. Int J Appl Basic Med Res. 2015 Aug; 5(Suppl 1): S76-S79. https://dx.doi. org/10.4103/2229-516X.162286

15. Sunita YP, Nayana KH, Bhagyashri RH. Blueprinting in assessment: How much is imprinted in our practice? J Educ Res Med Teach. 2014; 2:4-6. http://citeseerx.ist.psu.edu/viewdoc/download ;jsessionid=E331BA19B2CB29DCC5D44BCA68C 705BD?doi=10.1.1.683.9469\& $\mathrm{rep}=$ rep1\&type $=p$ df

16. Al Wahbi. The need for faculty training programs in effective feedback provision. Advances in Medical Education and Practice 2014:5 263-268 https://doi.org/10.2147/AMEP.S62889 